\section{Suitability of Composted Green Waste for Horticultural Uses}

\author{
T.K. Hartz, F.J. Costa, and W.L. Schrader ${ }^{1}$ \\ Department of Vegetable Crops, University of California, Davis, CA 95616
}

\author{
Additional index words. nitrogen, nutrient availability, Capsicum annuum, Lycopersicon \\ esculentum, Tagetes erecta
}

\begin{abstract}
The study was undertaken to determine the physiochemical properties and nutrient supply characteristics of composted green yard and landscape waste (CGW) and to document its performance as a field soil amendment or constituent of potting media. Three CGW samples were collected from each of two composting operations in California from Nov. 1993 to Apr. 1994. Macronutrient content varied widely between operations, and among samples from the same operation, with mean total $N, P$, and $K$ levels averaging $1.1 \%, 0.26 \%$, and $0.67 \%$, respectively. Controlled-environment incubation of a moist 1 CGW : 9 soil blend $\left(2\right.$ weeks at $30{ }^{\circ} \mathrm{C}$ ) was conducted to determine net $\mathrm{N}$ mineralization from CGW. Despite low C : N ratios $(<12)$, five of six CGW samples showed net immobilization, a characteristic of immature compost. An in-field incubation of soil amended with $1 \%$ or $2 \% \mathrm{CGW}$ (w/w) showed no net $\mathrm{N}$ release from CGW over 4 months. In a field trial, bell pepper (Capsicum annuum L.) fruit yield was increased by soil amendment with CGW (17 or $\left.34 \mathrm{t}^{\circ} \cdot \mathrm{ha}^{-1}\right)$ under a low $\mathrm{N}$ fertilizer regime $\left(168 \mathrm{~kg} \cdot \mathrm{ha}^{-1}\right)$, but was unaffected where sufficient fertilizer $N\left(280 \mathrm{~kg} \cdot \mathrm{ha}^{-1}\right)$ was applied. CGW was compared with peat as a constituent of potting media; both were blended 1:1 (v/v) with perlite and used in the production of tomato (Lycopersicon esculentum Mill.) and marigold (Tagetes erecta $\mathrm{L}$.) plants under varying fertigation regimes (constant feed of $\mathrm{N}$ at 0,50 , or 100 $\mathrm{mg} \cdot \mathrm{L}^{-1}$ as $\left.15 \mathrm{~N}-13 \mathrm{P}-12 \mathrm{~K}\right)$. CGW was equivalent or superior to peat in plant growth; CGW did contribute to crop macronutrient nutrition, but the highest fertigation rate was required for optimum growth.
\end{abstract}

In California, as in much of the United States, yard and landscape wastes have historically been disposed of in landfills. Recent California legislation mandated a 50\% reduction in the landfill waste stream by the year 2000. The practical effect of this legislation has been to require the recycling of green waste, which constituted $\approx 25 \%$ of the solid waste stream in California in 1990. Most of the material will undoubtedly be composted for agricultural use, as landscape mulch, soil amendment, or potting medium. Numerous green waste composting operations have been established across the state.

There has been considerable study of various types of municipal solid waste composts, with most attention centered on sewage sludgeamended products (Bryan and Lance, 1991; Falahi-Ardakani et al., 1987; Ozores-Hampton et al., 1994; Tester, 1989). Relatively few studies have evaluated composted municipal green waste (CGW), free of sludge, paper, and other organic wastes. CGW typically contains lower levels of heavy metals commonly present in sludge-based composts and are thus more

\footnotetext{
Received for publication 25 Sept. 1995. Accepted for publication 7 May 1996. The cost of publishing this paper was defrayed in part by the payment of page charges. Under postal regulations, this paper therefore must be hereby marked advertisement solely to indicate this fact.

${ }^{1}$ Univ. of California Cooperative Extension, San Diego County.
}

likely to be readily accepted by agriculture. To determine the most agriculturally and economically appropriate uses, the physiochemical and biological properties of CGW must be well understood. Previous reports (Hegberg et al., 1991; Rosen et al., 1993) show that considerable variability exists in $\mathrm{pH}$, electrical conductivity (EC), and macronutrient concentration among various CGW batches. Differences undoubtedly also exist in more difficultto-measure characteristics such as phytotoxicity and $\mathrm{N}$ mineralization/immobilization behavior. These differences relate to source material, composting technique, and degree of maturity.

This study was undertaken to document the physiochemical characteristics and $\mathrm{N}$ mineralization/immobilization dynamics of CGW samples representative of California sources. Furthermore, the effects of soil amendment with CGW on productivity of bell pepper and on soil properties were determined, as was the suitability of CGW as a replacement for peat in potting media.

\section{Materials and Methods}

CGW was obtained from two commercial operations, one in southern California $\left(S_{\mathrm{s}}\right)$, one in northern California $\left(S_{n}\right)$. Source material for both operations was yard and landscape waste (no paper, food wastes, or other organic materials). The material was ground, windrowed, and composted aerobically in windrows for 2 to 3 months. Three samples were collected from each source at 4- to 6week intervals, from Nov. 1993 to Apr. 1994; each sample was distinct, representing a windrow being used on-site as a constituent of potting media $\left(\mathrm{S}_{\mathrm{s}}\right)$ or offered for sale $\left(\mathrm{S}_{\mathrm{n}}\right)$ at the time of collection. All samples were screened through 12-mm mesh before analysis or use in any experiments.

Mineral $\mathrm{N}\left(\mathrm{NH}_{4}^{+}\right.$and $\left.\mathrm{NO}_{3}^{-}\right)$concentration was determined in $2 \mathrm{~N} \mathrm{KCl}$ extracts of compost, immediately after screening. EC was measured on 2 distilled water : 1 dry compost water extracts. Total $\mathrm{N}$ was determined by the combustion method of Sweeney (1989), total $\mathrm{C}$ by combustion and subsequent measurement by thermal electric conductivity. Total $P$ was determined by a colormetric technique following microwave acid digestion (Kingston and Jassie, 1986), K by atomic emission spectroscopy following $2 \%$ acetic acid extraction.

The presence of phytotoxic compounds was examined through a tomato seed bioassay. Air-dried compost $(8 \mathrm{~g})$ and $40 \mathrm{~mL}$ of distilled water were shaken for $2 \mathrm{~h}$ then filtered; the extract was diluted 1:1 with distilled water. Seven milliliters of solution was added to a petri dish containing a filter-paper blotter. Seed of 'Brigade' tomato were added and the petri dishes incubated 3 days at $23 \pm 1{ }^{\circ} \mathrm{C}$. A germination index was calculated by the method of Zucconi and de Bertoldi (1987).

Nitrogen mineralization/immobilization behavior of CGW was measured in a controlled-environment incubation of soil : CGW blends. The soil used was a Vista coarse sandy loam collected from a field in long-term vegetable production. A dry 9 soil : $1 \mathrm{CGW}$ blend (w/w) was moisture-equilibrated at $0.25 \mathrm{kPa}$ for $48 \mathrm{~h}$ then incubated at $30^{\circ} \mathrm{C}$ for 14 days in beakers covered with 25 - $\mu$-thick polyethylene. There were five replicate beakers per CGW sample. The difference in mineral $\mathrm{N}$ over the incubation period (measured in $2 \mathrm{~N}$ $\mathrm{KCl}$ extracts of moist blend) represented net mineralization/immobilization.

An in-field incubation of CGW-amended soil was conducted in a commercial vegetable field in Carlsbad, Calif. The field soil, a Vista coarse sandy loam most recently cropped with green beans (Phaseolus vulgaris L.), was used. CGW $\left(\mathrm{S}_{\mathrm{s}}\right.$, sample a; Table 1$)$ was added to soil at $1 \%$ or $2 \%$ by dry weight. The CGW : soil blends were mixed in a rotary mixer to ensure uniform distribution, then screened through $12-\mathrm{mm}$ mesh. PVC tubes $(30 \mathrm{~cm}$ long, $5 \mathrm{~cm}$ wide) were filled with the blend (at $10 \%$ moisture by weight) and packed to approximate normal field bulk density. The PVC tubes were fitted on the bottom with a bed of anion exchange resin (Dowex 1-X8; Bio Rad Laboratories, Richmond, Calif.) with high affinity for nitrate; $\mathrm{NO}_{3}-\mathrm{N}$ in leachate flowing through the resin was captured on the resin (Schnabel, 1983). There were 12 tubes per compost rate. The PVC tubes were buried 1 Nov. 1993 at ground level; the tubes were open at the top to allow rain to percolate through the soil column. Due to the abnormally dry weather encountered $(11 \mathrm{~mm}$ rain over the incubation period), $25 \mathrm{~mm}$ additional water was added to the tubes to keep the soil columns moist. Tubes were removed 15 Feb. 1994. Soil was 


\begin{tabular}{|c|c|c|c|c|c|c|c|c|c|c|c|}
\hline \multirow[b]{2}{*}{ CGW source } & \multirow{2}{*}{$\begin{array}{c}\mathrm{EC}^{\mathrm{z}} \\
\left(\mathrm{dS} \cdot \mathrm{m}^{-1}\right)\end{array}$} & \multirow{2}{*}{$\begin{array}{c}\mathrm{CEC}^{\mathrm{y}} \\
(\mathrm{meq} / 100 \mathrm{~g})\end{array}$} & \multicolumn{2}{|c|}{ Mineral $N\left(\mu \mathrm{g} \cdot \mathrm{g}^{-1}\right)$} & \multirow[b]{2}{*}{$\mathrm{C} / \mathrm{N}$} & \multicolumn{4}{|c|}{ Dry wt $(\%)$} & \multirow{2}{*}{$\begin{array}{c}\mathrm{N} \\
\text { availability } \\
\text { index }^{\mathrm{x}} \\
\end{array}$} & \multirow{2}{*}{$\begin{array}{l}\text { Germi- } \\
\text { nation } \\
\text { index }^{w}\end{array}$} \\
\hline & & & $\mathrm{NH}_{4}-\mathrm{N}$ & $\mathrm{NO}_{3}-\mathrm{N}$ & & $\mathrm{N}$ & $\mathrm{P}$ & $\mathrm{K}$ & Ash & & \\
\hline \multirow{3}{*}{$\begin{array}{ll}\mathrm{S}_{\mathrm{s}} & \mathrm{a} \\
& \mathrm{b} \\
& \mathrm{c}\end{array}$} & 11.4 & 29.9 & 339 & 5 & 11.1 & 1.01 & 0.20 & 0.45 & 73.3 & $-8.4(3.2)^{\mathrm{v}}$ & $86(21)$ \\
\hline & 14.7 & 32.2 & 341 & 20 & 10.8 & 1.18 & 0.23 & 0.72 & 70.0 & $-8.4(1.7)$ & $20(15)$ \\
\hline & 12.8 & 30.7 & 39 & 15 & 11.8 & 0.74 & 0.20 & 0.61 & 63.5 & $-13.6(0.3)$ & $55(18)$ \\
\hline \multirow{3}{*}{$\begin{array}{ll}S_{\mathrm{n}} & \mathrm{a} \\
& \mathrm{b} \\
& \mathrm{c}\end{array}$} & 5.8 & 44.3 & 98 & 5 & 10.2 & 1.23 & 0.29 & 0.67 & 57.8 & $-6.3(1.1)$ & $96(16)$ \\
\hline & 7.7 & 38.7 & 15 & 320 & 9.2 & 1.27 & 0.31 & 0.83 & 61.4 & $-5.6(2.3)$ & 69 (19) \\
\hline & 8.3 & 42.2 & 56 & 53 & 8.9 & 1.40 & 0.31 & 0.73 & 62.4 & $+5.1(1.7)$ & $84(16)$ \\
\hline
\end{tabular}

${ }^{2} \mathrm{EC}=$ electrical conductivity.

${ }^{\mathrm{y}} \mathrm{CEC}=$ cation exchange capacity.

${ }^{\mathrm{x}}$ Change in mineral $\mathrm{N}$ content $\left(\mu \mathrm{g} \cdot \mathrm{g}^{-1}\right)$ during 14-day incubation of a $10 \% \mathrm{CGW} /$ soil blend relative to nonamended soil; negative numbers indicate net immobilization. Mean of five replicate samples.

wTomato seed germination and radicle development in compost extract, in relation to distilled water control.

${ }^{v}$ Standard error.

extracted in $2 \mathrm{~N} \mathrm{KCl}$ and analyzed for mineral $\mathrm{N}$; the anion resin from each tube was extracted sequentially with two aliquots of 200 $\mathrm{mL} 1 \mathrm{~N} \mathrm{KCl}$ to recover adsorbed $\mathrm{NO}_{3}-\mathrm{N}$. The change in total mineral $\mathrm{N}$ in the soil over the incubation period, plus $\mathrm{NO}_{3}-\mathrm{N}$ recovered from the resin, represented net mineralization.

A field trial was conducted at the Univ. of California-Davis to determine the effects of soil amendment with CGW on crop productivity and soil physical properties. A Yolo silty loam soil (mixed, nonacid, thermic Typic xerorthent) was amended with $\mathrm{CGW}\left(\mathrm{S}_{\mathrm{n}}\right.$, sample c) on $25 \mathrm{Apr} .1994$ and tilled into raised beds to a depth of $\approx 15 \mathrm{~cm}$ with a power tiller. The design was a split plot within a randomized complete block. The main plot was $\mathrm{N}$ fertilizer rate (seasonal $\mathrm{N}$ application of 168 or $280 \mathrm{~kg} \cdot \mathrm{ha}^{-1}$ ); the split plot was CGW rate $(0,17$, and $34 \mathrm{tdry}$ weight/ha). There were five $1.5 \times 11-\mathrm{m}$ replications per fertilizer/ CGW combination. The low $\mathrm{N}$ fertilizer rate was assumed to be marginally deficient for optimum pepper growth, the high rate clearly sufficient (Hartz et al., 1993); the intent was to assess CGW effects on $\mathrm{N}$ supply and crop productivity.

'Jupiter' pepper transplants were planted 12 May, in a single row per $0.75-\mathrm{m}$ raised bed configuration, at a population of 43,000/ha. Plots were drip-irrigated, with water applied $3 \times$ per week; irrigation volume was based on reference evapotranspiration (ET) and crop canopy development. Nitrogen was delivered during irrigation in 10 equal weekly applications. A single comprehensive fruit harvest was conducted 26 Aug. At harvest, three whole plants per subplot were collected, dried, and analyzed to determine total crop biomass and macronutrient content. Following harvest, soil (0- to 30-cm depth) was collected and analyzed for organic matter content (Nelson and Sommers, 1982) and total Kjeldahl N (Issac and Johnson, 1976).

A greenhouse trial was conducted to evaluate CGW as a substitute for peat in bedding plant media. A $1 \mathrm{CGW}\left(\mathrm{S}_{\mathrm{s}}\right.$, sample c) : 1 perlite blend was compared with a 1 peat : 1 perlite medium for the production of bedding plants. The media were thoroughly leached to remove soluble salts. One month later (25 Apr. 1994) 'Bonanza' marigold and 'Brigade' tomato were seeded in 7.5-cm pots. Three levels of fertility were imposed: $\mathrm{N}$ at 0,50 , or $100 \mathrm{mg} \cdot \mathrm{L}^{-1}$ constant feed (as $15 \mathrm{~N}-13 \mathrm{P}-12 \mathrm{~K}$ plus trace elements) with each watering. The intent was to evaluate the macronutrient contribution of the CGW. The experimental design was a randomized complete block with 12 singlepot replications of each treatment combination (media $\times$ fertility). Plants were evaluated when the first treatment combination reached commercial size, which was 9 June (tomato) or 16 June (marigold). After harvest, plants were dried, ground, and assayed for macronutrient content, as previously described. Due to the limited amount of tissue, analysis was performed on a composite sample from each treatment.

\section{Results and Discussion}

Characteristics of CGW. The physiochemical characteristics of CGW differed substantially among samples tested (Table 1). $\mathrm{S}_{\mathrm{s}}$ was higher in soluble salt content (EC) and percent ash but lower in $\mathrm{N}, \mathrm{P}, \mathrm{K}$, and cation exchange capacity (CEC) than $\mathrm{S}_{\mathrm{n}}$; there also was substantial within-source variability among the three samples collected over time. Generally, macronutrient content was somewhat lower than is typical of more conventional agricultural soil amendments (i.e., composted manure), while the ash content was higher; this result reflected the substantial quantity of relatively inert material (bark, tree trimming, etc.) present in the $\mathrm{CGW}$ source material. Higher EC of $S_{s}$ was expected, given the region's poor water quality and higher evapotranspiration rates; the levels encountered would be of little concern to farmers using CGW as a soil amendment at typical rates but would mandate thorough leaching before use as a potting medium.

All CGW samples contained a small number of viable weed seeds, the majority of which were California burclover (Medicago hispida Gaertn.); seed of this plant also have proven resistant to chemical fumigation (Wilhelm and Paulus, 1980). Seed of other broadleaf weeds and grasses were well controlled by the composting process. Extracts of several CGW samples were inhibitory to tomato seed germination (Table 1). Compost phytotoxicity has been attributed to high $\mathrm{NH}_{4}^{+}$concentration or to organic acids that are present in damaging levels only in immature compost (Zucconi et al., 1981). Another indication of the immaturity of some CGW samples was net $\mathrm{N}$ immobilization, documented in the controlledenvironment incubation.

In-field incubation showed that $\mathrm{N}$ immobilization, expressed as reduced net $\mathrm{N}$ mineralization of CGW-amended soil, persisted for several months under field conditions (Table 2). The effect of CGW amendment at $1 \%$ and $2 \%$ was similar; orthogonal comparison of nonamended and compost-amended soils documented significant net Nimmobilization.

Field trial. Soil amendment with CGW improved marketable pepper yield at the low $\mathrm{N}$ fertigation regime $\left(\mathrm{N}\right.$ at $168 \mathrm{~kg} \cdot \mathrm{ha}^{-1}$ ) but had no effect at the higher rate (Table 3 ). Plant response was similar with both CGW rates tested $\left(17\right.$ and 34 toha $\left.{ }^{-1}\right)$. Fruit size and cull rate were unaffected. Potassium uptake was higher in CGW-amended plots. At the end of the growing season, residual effects of CGW application were apparent in elevated soil organic matter and total $\mathrm{N}$ levels.

Greenhouse trial. The growth of tomato and marigold seedlings in CGW/perlite potting mix was equivalent or superior to that in peat/perlite (Table 4). There were no differences between media in seed germination percentage nor was there any visible difference in root development or plant health. Macronutrient content of plants grown in CGW was substantially higher than that of plants grown in peat, suggesting that $\mathrm{CGW}$ was supplying some N, P, and K for plant uptake. However, the large increase in dry weight and macronutrient content in CGW-grown plants with increased soluble fertilizer application indicated that CGW supplied a relatively small fraction of plant requirements for optimum plant growth. When fresh, CGW used in this test showed net $\mathrm{N}$ immobilization and a moderate level of phytotoxicity in the tomato seedling bioassay. The month between leaching the blended media and initiating the greenhouse trial may have allowed microbial activity to moderate those undesirable characteristics.

These results demonstrate that considerable variability exists in CGW from differing sources, and over time from the same source. Differences in macronutrient content are easily measured but the practical significance of that information was less clear. Despite low C : $\mathrm{N}$ ratios $(<12)$, five of six CGW samples tested showed substantial net $\mathrm{N}$ immobiliza- 
Table 2. Nitrogen mineralization during in-field incubation (1 Nov. 1993 to 15 Feb. 1994) of composted green waste $(\mathrm{CGW})$-amended soil.

\begin{tabular}{lccc}
\hline CGW & $\begin{array}{c}\text { Soil mineral N increase } \\
\left(\mu \mathrm{g} \cdot \mathrm{g}^{-1}\right)\end{array}$ & $\begin{array}{c}\text { Leachate } \mathrm{NO}_{3}-\mathrm{N}^{z} \\
\left(\mathrm{~g} \cdot \mathrm{m}^{-2}\right)\end{array}$ & $\begin{array}{c}\text { Net } \mathrm{N} \\
\text { mineralization } \\
\left(\mu \mathrm{g}^{\mathrm{y}} \mathrm{g}^{-1}\right)\end{array}$ \\
\hline- & 31 & 9.7 & 52 \\
$+^{\mathrm{x}}$ & 18 & 9.4 & 39 \\
$\begin{array}{l}\text { Nonamended vs. } \\
\text { compost-amended }\end{array}$ & $*$ & $\mathrm{NS}$ & $*$ \\
\hline
\end{tabular}

${ }^{2} \mathrm{NO}_{3}-\mathrm{N}$ extracted from anion resin traps.

${ }^{\mathrm{y}}$ Bulk density $=1.5 \mathrm{~g} \cdot \mathrm{cm}^{-3}$.

${ }^{x}$ At $1 \%$ and $2 \%$ by dry weight.

Ns, "Nonsignificant or significant at $P \leq 0.05$, respectively.

Table 3. Effect of soil amendment with composted green waste (CGW) on bell pepper production and residual soil properties following fertilization with $168 \mathrm{~kg} \mathrm{~N} / \mathrm{ha}$.

\begin{tabular}{|c|c|c|c|c|c|c|c|}
\hline \multirow[b]{2}{*}{ CGW } & \multirow{2}{*}{$\begin{array}{c}\text { Marketable fruit } \\
\text { yield } \\
\text { (kg/plant) }\end{array}$} & \multirow{2}{*}{$\begin{array}{c}\text { Plant } \\
\text { biomass } \\
\text { (g dry wt) }\end{array}$} & \multicolumn{3}{|c|}{$\begin{array}{c}\text { Macronutrient content } \\
\text { (g/plant) }\end{array}$} & \multicolumn{2}{|c|}{ Soil properties $(\%)^{\mathrm{z}}$} \\
\hline & & & $\mathrm{N}$ & $\mathrm{P}$ & $\overline{\mathrm{K}}$ & Organic matter & $\overline{T^{2} N^{y}}$ \\
\hline- & 1.41 & 213 & 6.2 & 0.58 & 7.4 & 1.26 & 0.078 \\
\hline$+^{\mathrm{x}}$ & 1.56 & 228 & 6.8 & 0.68 & 9.3 & 1.35 & 0.087 \\
\hline $\begin{array}{l}\text { Nonamended vs. } \\
\text { compost-amended }\end{array}$ & $*$ & NS & NS & NS & $*$ & $* *$ & $*$ \\
\hline
\end{tabular}

tion, indicating a net movement of $\mathrm{N}$ into microbial biomass. The immobilization was undoubtedly related to low $\mathrm{N}$ content of the composts, but compost maturity was also a factor. Unfortunately, determining compost maturity is problematic; there is no consensus on what analytical procedures best predict compost maturity, and most of the more promising tests (Herrmann and Shann, 1993; Inbar et al., 1990) are impractical for routine use in the commercial compost industry. Economic forces compel composters of green yard and landscape waste, be they municipalities or private contractors, to seek quick product turnover with minimal cost input. Additional time and handling required to prepare mature, biologically stable compost would have to be justified by an increase in the value of the finished product.

It is difficult to quantify economic benefit from soil amendment with CGW. In the field trial, high rates of application ( 2 to 4 times the rate common in the vegetable industry) gave a marginal yield increase under a limited $\mathrm{N}$ application regime; with a sufficient fertilizer program, no crop production benefits were observed. Importantly, the CGW used in the field trial was the only sample studied that showed net $\mathrm{N}$ mineralization in the controlled- environment incubation. From a grower perspective, the unpredictability of nutrient release from CGW would minimize its value as a fertilizer. The importance of other potential benefits of CGW (improved tilth, increased microbial activity, disease suppression) would vary considerably from site to site; there are few scientifically valid studies documenting the significance of these benefits under representative field conditions. If soil amendment is the end use of CGW, the composter likely would require a substantial tipping fee to subsidize the composting process.

A higher value use of CGW would be as a substitute for peat or other expensive organic materials in potting media, which commonly cost $\$ 25.00 / \mathrm{m}^{3}$ or more. CGW showed great promise for this use, in this and in previous studies (Bugbee and Frink, 1989; Purman and Gouin, 1992; Rosen et al., 1993). For this application, consistency of performance would be critical, as would sufficient leaching to remove soluble salts. Compost maturity would be an issue, from several standpoints: the presence of phytotoxic compounds or viable weed seed, $\mathrm{N}$ dynamics, and the disease suppressive capability of the microflora (Hoitink et al., 1993).

In summary, CGW is not a homogeneous material, varying in physiochemical and biological properties among sources, and among batches from a given source. Standardized evaluation procedures are needed to allow the end user to determine the value of, and appropriate use for, CGW.

\section{Literature Cited}

Bryan, H.H. and C.J. Lance. 1991. Compost trial on vegetables and tropical crops. Biocycle 32(3):3637.

Bugbee, G.J. and C.R. Frink. 1989. Composted waste as a peat substitute in peat-lite media. HortScience 24:625-627.

Falahi-Ardakani, A., J.C. Bouwkamp, F.R. Gouin, and R.L. Chaney. 1987. Growth response and mineral uptake of vegetable transplants grown in a composted sewage sludge amended medium. I. Nutrient supplying power of the medium. J. Environ. Hort. 5:107-111.

Hartz, T.K., M. LeStrange, and D.M. May. 1993. Nitrogen requirements of drip-irrigated pepper. HortScience 28:1097-1099.

Hegberg, B.A., W.A. Hallenbach, G.R. Brenniman, and R.A. Wadden. 1991. Setting standards for yard waste compost. Biocycle 32(2):58-61.

Herrmann, R.F. and J.R. Shann. 1993. Enzyme activities as indicators of municipal solid waste compost maturity. Compost Sci. \& Utilization 1(4):54-63.

Hoitink, H.A.J., M.J. Boehm, and Y. Hadar. 1993. Mechanisms of suppression of soilborne plant pathogens in compost-amended substrates, $\mathrm{p}$. 601-621. In: H.J. Hoitink and H.M. Keener (eds.). Science and engineering of composting: Design, environmental, microbiological and utilization aspects. Ohio State Univ., Columbus.

Inbar, Y., Y. Chen, Y. Hadar, and H.A.J. Hoitink. 1990. New approaches to compost maturity. Biocycle 31(12):64-69.

Issac, R.A. and W.C. Johnson. 1976. Determination of total nitrogen in plant tissue. J. Assn. Official Anal. Chem. 59:98-100.

Kingston, H.M. and L.B. Jassie. 1986. Microwave energy for acid decomposition at elevated temperatures and pressures using biological and botanical samples. Anal. Chem. 58:2534-2541.

Nelson, D.W. and L.E. Sommers. 1982. Total carbon, organic carbon and organic matter, p. 539580. In: A.L. Page (ed.). Methods of soil analysis: Part 2. Chemical and microbiological properties. Amer. Soc. Agron. Monogr. 9. Amer. Soc. Agron., Madison, Wis.

Ozores-Hampton, M., B. Schaffer, and H.H. Bryan. 1994. Nutrient concentrations, growth and yield of tomato and squash in municipal solid-wasteamended soil. HortScience 29:785-788.

Purman, J.R. and F.R. Gouin. 1992. Influence of compost aging and fertilizer regimes on the growth of bedding plants, transplants and poinsettia. J. Environ. Hort. 10:52-54.

Table 4. Performance of composted green waste (CGW) as a constituent of bedding plant media.

\begin{tabular}{|c|c|c|c|c|c|c|c|c|c|c|c|c|c|}
\hline \multirow[b]{3}{*}{ Crop } & \multirow{3}{*}{$\begin{array}{c}\mathrm{N}^{\mathrm{z}} \\
\left(\mathrm{mg} \cdot \mathrm{L}^{-1}\right)\end{array}$} & \multirow{2}{*}{\multicolumn{3}{|c|}{ Plant ht $(\mathrm{cm})$}} & \multirow{2}{*}{\multicolumn{3}{|c|}{ Plant dry wt (g) }} & \multicolumn{6}{|c|}{ Tissue N concn $(\%)$} \\
\hline & & & & & & & & \multicolumn{2}{|c|}{$\mathrm{N}$} & \multicolumn{2}{|c|}{$\mathrm{P}$} & \multicolumn{2}{|c|}{$\mathrm{K}$} \\
\hline & & Peat ${ }^{y}$ & & $\mathrm{CGW}$ & Peat & & CGW & Peat & CGW & Peat & CGW & Peat & CGW \\
\hline \multirow[t]{3}{*}{ Marigold } & 0 & 6.5 & * & 9.7 & 0.11 & $*$ & 0.25 & 0.8 & 2.2 & 0.16 & 0.51 & 2.6 & 4.5 \\
\hline & 50 & 11.7 & NS & 11.4 & 0.48 & NS & 0.59 & 2.4 & 3.1 & 0.56 & 0.68 & 4.6 & 6.6 \\
\hline & 100 & 13.0 & NS & 12.2 & 0.86 & NS & 0.86 & 2.9 & 3.7 & 0.66 & 0.67 & 4.7 & 6.3 \\
\hline \multirow[t]{3}{*}{ Tomato } & 0 & 9.5 & $*$ & 6.4 & 0.09 & $*$ & 0.21 & 1.1 & 1.8 & 0.24 & 0.69 & 2.0 & 3.9 \\
\hline & 50 & 13.2 & NS & 12.4 & 0.43 & NS & 0.44 & 2.1 & 2.4 & 0.65 & 0.62 & 3.2 & 4.1 \\
\hline & 100 & 18.0 & NS & 18.0 & 0.68 & $*$ & 0.78 & 2.7 & 2.7 & 0.67 & 0.66 & 4.0 & 5.2 \\
\hline
\end{tabular}

${ }^{2}$ Constant feed as $15 \mathrm{~N}-13 \mathrm{P}-12 \mathrm{~K}$ plus trace elements.

yeat or CGW blended 1:1 by volume with perlite.

ss, "Nonsignificantly or significantly different, respectively, by paired comparison $(P \leq 0.05)$. 


\section{Soil Management, Fertilization, \& Irrigation}

Rosen, C.J., T.R. Halbach, and B.T. Swanson. 1993. Horticultural uses of municipal solid waste composts. HortTechnology 3:167-173.

Schnabel, R.R. 1983. Measuring nitrogen leaching with ion exchange resin: A laboratory assessment. Soil Sci. Soc. Amer. J. 47:1041-1042.

Sweeney, R.A. 1989. Generic combustion method for determination of crude protein in feeds: Collaborative study. J. Assn. Official
Anal. Chem. 72:770-774.

Tester, C.F. 1989. Tall fescue growth in greenhouse, growth chamber and field plots amended with sludge compost and fertilizer. Soil Sci. 148:452458.

Wilhelm, S. and A.O. Paulus. 1980. How soil fumigation benefits the California strawberry industry. Plant Dis. 64:264-270.

Zucconi, F. and M. deBertoldi. 1987. Compost specifications for the production and characterization of compost from municipal solid waste, p. 30-50. In: M. deBertoldi, M.M. Ferranti, R. L'Hermite, and F. Zucconi (eds.). Compost: Production, quality and use. Elsevier Applied Science, London.

Zucconi, F., A. Pera, M. Forte, and M. deBertoldi. 1981. Evaluating toxicity of immature compost. Biocycle 22(2):54-57. 